\title{
ВИКОРИСТАННЯ ПРИВЕНТИВНОГО АНТИКРИЗОВОГО УПРАВЛІННЯ В ДІЯЛЬНОСТІ ПІДПРИЕМСТВ
}

\section{ИСПОЛЬЗОВАНИЕ ПРЕВЕНТИВНОГО АНТИКРИЗИСНОГО УПРАВЛЕНИЯ В ДЕЯТЕЛЬНОСТИ ПРЕДПРИЯТИЙ}

\section{THE USE OF PREVENTIVE ANTI-CRISIS MANAGEMENT IN THE ENTERPRISE}

У статті розглянуто роль превентивного антикризисного управління на основі комплексних заходів до подолання кризових ситуачій. Розглядаються причини і моменти настання кризи, а у разі об'єктивної неможливості уникнути входження в кризовий період, зазначені підходи до їх подолання. Визначені основні поняття антикризового управління, превентивного управління та превентивного антикризового управління, що $\epsilon$ дієвими інструментами управління кризовими станами, в умовах ичиклічності кризових явищ. Розкрито основні завдання превентивного антикризового управління, та представлено оцінку ймовірності виникнення та аналізу наслідків впливу потенційних кризових явищ та ситуацій, при розробизі антикризової стратегї, реалізації планів заходів щзодо попередження криз. Виділено ключові напрямки превентивного управління та необхідні інструменти, при реалізації антикризових заходів на підприємстві. Представлено застережні функиї при загрозі кризи, які будуть виконуватись службою кризового попередження.

Ключові слова: антикризове управління, превентивне управління, превентивне антикризове управління.

В статье рассмотрена роль превентивного антикризисного управления на базе комплексных мер по преодолению кризисных ситуащий. Рассматриваются причины и моменты наступления кризиса, а в случае объективной невозможности избежать

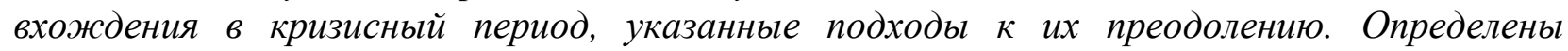
основные понятия антикризисного управления, превентивного управления и превентивного антикризисного управления, которые являются действенными инструментами управления кризисныли состояниями, в условиях ияикличности кризисных явлений. Раскрыты основные задания превентивного антикризисного управления, и представлено оценку вероятности возникновения и анализа последствий влияния потенщиальных кризисных явлений $u$ ситуаций, при разработке антикризисной стратегии, реализачии планов мероприятий по предупреждению кризисов. Выделены ключевые направления превентивного управления и необходимые инструменты, при реализации антикризисных мер на предприятии. Представлень меры функции при угрозе кризиса, которые будут выполняться службой кризисного предупреждения.

Ключевые слова: антикризисное управление, превентивное управление, превентивное антикризисное управление. 
The article discusses the role of preventive crisis management on the basis of comprehensive measures to overcome the crisis. The reasons and aspects of the crisis, as in the case of objective impossibility to avoid the occurrence of the crisis period, these approaches to overcoming them. The basic concepts of crisis management, preventive management and preventive crisis management, which are effective crisis management instruments states, in conditions of cyclical crises. It outlines the main tasks of preventive crisis management, and provides an assessment of the likelihood and consequences of the analysis of the impact of potential crises and situations in the development of anti-crisis strategy, the implementation of action plans to prevent crises. Highlight key areas of preventive management and the necessary tools in the implementation of anti-crisis measures in the enterprise. Presented measure function when the threat of the crisis, which will be performed the service of crisis prevention.

Keywords: crisis management, proactive management, proactive crisis management.

Вступ. Трансформаційний розвиток світової економіки в умовах глобалізації, посилило негативний вплив на вітчизняний сектор економіки i збільшило ризики підприємницької діяльності. Численні ризики в сучасних умовах, впливаючи один на одного, викликають ще більші втрати, знижують ефективність i конкурентоспроможність підприємницьких структур. Багатоаспектність ризиків, ускладнюють їх прогнозування, адекватну оцінку та розробку ефективних методів управління.

Нестабільна діяльність українських підприємств, обумовлює актуальність домінуючої ролі превентивного антикризисного управління промисловим підприємством, що дозволить підприємницьким структурам цілеспрямовано і з попередженням реагувати на виникаючі ризики. Необхідно також відзначити, що характерні для промислового підприємництва ризики утворюють систему взаємопов'язаних ризиків, управління якими вимагає врахування їх взаємозв'язків і розробку та реалізацію превентивних заходів, спрямованих на розрив ланцюжків ризиків і зниження негативних наслідків їх впливу.

Теоретичну базу дослідження становлять праці вітчизняних та зарубіжних фахівців 3 питань управління підприємницькими ризиками в умовах кризового стану, зокрема розглядається в наукових роботах П.Друкера [1], М.Портера., В.М. Багацького, О.І. Барановського, О.Р. Беднарської, Н.Д. Гетманцевої, В.В. Лук'янової, О.В. Коваленко [2], О.С. Кузьміна, В.О. Куніна [3], Н.Ю. Подольчак, А.С. Полянської, В.М. Распова [4], 3.С. Шершньової [7] та інших, в яких внаслідок важливості ролі превентивного антикризового управління, основну увагу приділено видам управлінських ризиків.

Постановка завдання. Основною метою статті є розкрити визначальну роль в подоланні кризових явищ в підприємницькій діяльності, в умовах наростаючих «хвильоподібних» кризових ситуаціях, на основі превентивного управління промисловим підприємством, що дозволяє цілеспрямовано і 3 випередженням реагувати на виникаючі ризики, відвертаючи загрозу недопустимого зниження ефективності підприємницької діяльності. 
Методологія. Теоретико-методологічну основу роботи становлять розробки вітчизняних та зарубіжних вчених у сфері антикризисного управління підприємствами. Для досягнення поставленої мети використано такі загальнонаукові та спеціальні методи дослідження: системний та порівняльний аналіз - при розробленні комплексу заходів за ключовими напрямами діяльності сфер превентивного управління; абстрактнотеоретичний - при вивченні суті й визначенні напрямів удосконалення підходів до антикризисного управління; гіпотетичний метод та метод логічного узагальнення - при розробленні основних рекомендацій, щодо використання елементів антикризових заходів.

Результати дослідження. В сучасних умовах, одним 3 головних критеріїв успішного розвитку бізнесу є його забезпечення стійким розвитком. Створення такого стану можливе лише за умов активного впровадження нових технологій i продукції, прогресивних конкурентних стратегій та превентивного підходу до управління підприємством. То ж безпосередній вплив на діяльність підприємства, в умовах швидкоплинних змін, мають змінюючи один-одного ризики.

Для запобігання негативним процесам у функціонуванні підприємства, доцільно виявляти ранні ознаки настання кризових явищ. Виявлення негативних явищ на ранніх стадіях, що призводять до руйнування діяльності, може допомогти підвищити ймовірність збереження стійкого розвитку. Превентивні заходи дозволяють значно знизити витрати ресурсів на забезпечення виконання поставлених завдань, тому що витрати на виявлення та ліквідацію несприятливих факторів значно нижче, ніж на ліквідацію наслідків кризи, яку вони можуть викликати. Грунтується превентивне антикризове управління на принципі запобігання загрозі кризи, iз послідуючим забезпеченням нейтралізації можливих негативних наслідків. Реалізація даного принципу забезпечується за допомогою ранньої діагностики передкризового стану підприємства і своєчасного використання можливостей нейтралізації кризи.

Антикризове управління - це комплекс заходів за попередньою оцінкою ймовірності та можливих наслідків потенційних криз, виявлення перших ознак криз, розробки антикризової стратегії, виконання планів антикризових заходів щодо попередження та ліквідації кризової ситуації, ліквідації наслідків кризи і запобіганню можливості появи кризових ситуацій у перспективі [7].

Превентивне управління грунтується на своєчасній ідентифікації елементів кризових явищ і передбачає розробку комплексу організаційноекономічних та управлінських програм, спрямованих на запобігання кризовим ситуаціям. 
Превентивне антикризове управління - це комплекс заходів із відстеження внутрішніх і зовнішніх можливостей, та розробки і реалізації антикризових процедур [4].

До завдань превентивного антикризового управління відносять оцінку ймовірності виникнення та аналізу наслідків впливу потенційних кризових явищ та ситуацій, розробка антикризової стратегії, реалізація планів заходів щодо попередження криз.

Превентивне антикризове управління грунтується на проведенні заходів щодо ідентифікації, оцінки та управління ризиками організації та вирішенні питань підвищення економічної безпеки підприємства, шляхом збільшення здатності організації до адаптації кризових умов [5].

В науковій літературі, превентивне антикризове управління розглядають в двох площинах [7]:

1) раннє антикризове управління, яке здійснюється 3 метою подолання небезпеки кризи та створення потенціалу прибутковості у разі загасання попиту і погіршення позицій організації на ринку і небезпеки втрати його самого;

2) антикризове управління по слабких сигналах про загрозу кризи, яке реалізується при втраті конкурентоспроможності продукції та організації в цілому.

При превентивному управлінні підприємство повинно бути більше орієнтоване на випереджаюче управління, а не вирішувати проблеми при їх виникненні. Для ефективної боротьби з кризами основну увагу слід приділяти не оперативному реагуванню на кризові ситуації, а попереджати та прогнозувати їі появу заздалегідь.

Своєчасне виявлення можливості настання кризового стану та вчасне прийняття превентивних заходів щодо попередження кризи, є ключовим завданням антикризового управління.

Реалізація превентивного управління на підприємстві повинна відбуватись завдяки використанню комплексу заходів за ключовими напрямами діяльності (рисунок):

1) сфера виробничої діяльності.

- грамотне та своєчасне планування господарської діяльності в короткостроковому, середньостроковому та довгостроковому періодах;

- визначення нових та перспективних ринків збуту продукції;

- розробка нових частин та матеріалів продукції, реінжиніринг;

- можливість диверсифікації продукції;

- розробка альтернативних стратегій діяльності підприємства в умовах песимістичної прогнозної діяльності;

2) функціональна сфера діяльності. 
- перехід до превентивних технологій управління;

- запровадження ощадного виробництва;

- реалізація засобів з реструктуризації підприємства;

3) сфера управління.

- створення умов для підвищення працевіддачі;

- використання ефективних інструментів справедливої мотивації праці;

- створення умов для творчої активності;

- запровадження системи обміну знаннями в організації.

Аналізуючи зазначені заходи, необхідно відзначити два ключові напрямки, які постійно повинні бути присутні в усіх сферах превентивного управління: постійне впровадження інновацій та діяльність кризового підрозділу.

Постійне впровадження інновацій в антикризовому управлінні - це одна 3 необхідних складова ефективного функціонування сучасної організації. Головною метою інновацій в антикризовому управлінні $\epsilon$ створення превентивної системи управління організацією. Серед ключових форм таких інновацій можна виділити:

- запровадження постійного функціонування електронного документообігу;

- запровадження ефективної діяльності бізнес-процесів;

- управління та підтримка внутрішньоорганізаційних знань та потреб;

- використання інструментів постійного діалогу із зовнішнім середовищем.

Дослідження превентивного антикризового управління на основі пошуку прийнятних варіантів організаційного управління, дає можливість запровадити нову функціональну організаційну одиницю, як службу кризового попередження, та визначити їх завдання i функції. До числа їх основних завдань можна віднести:

- створення та забезпечення функціонування систем збору інформації для своєчасного виявлення причин і факторів розвитку криз, як у зовнішньому, так і у внутрішньому середовищі;

- розробка інструментів аналізу факторів, що впливають на розвиток неплатоспроможності підприємства;

- розробка кризового плану на випадок розгортання кризи;

- надання консультаційної підтримки при розробці стратегії і тактики розробки та просування продукції;

- розробка пропозицій із боротьби з кризовими явищами підприємства;

- своєчасне попередження вищого керівництва підприємства про необхідність прийняття антикризових рішень;

- визначення бажаної швидкості прийняття превентивних заходів, складання бюджету необхідних витрат, часу і засобів для їх реалізації; 
визначення можливого ефекту від реалізації запропонованих антикризових заходів.

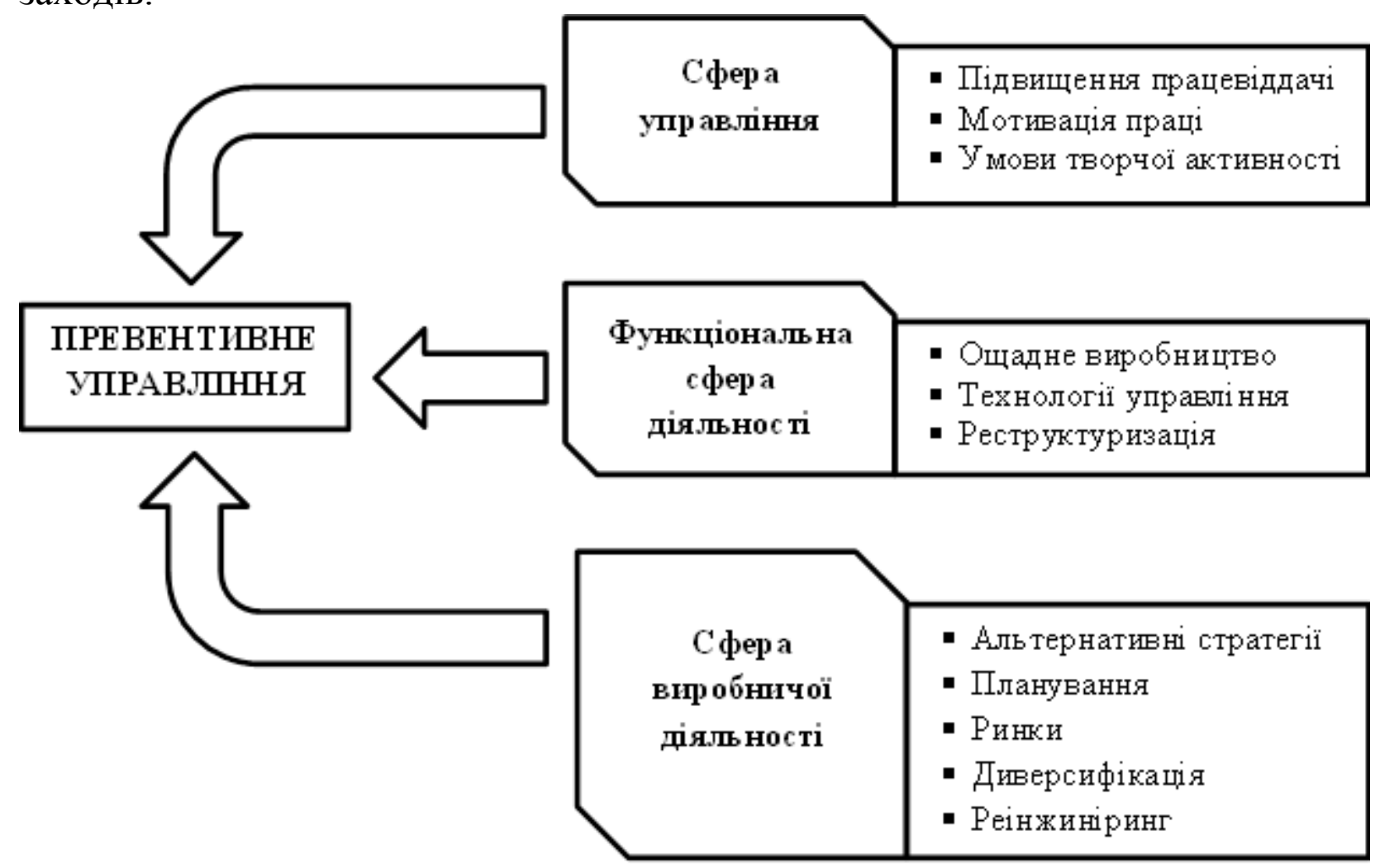

Рисунок. Комплекс заходів $з$ превентивного управління за сферами діяльності Джерело: розроблено автором

Постійна загроза кризи обумовлює необхідність виділення і посилення застережних функцій, які будуть виконуватись службою кризового попередження, до яких слід віднести діагностику та прогнозування криз. Суть функції діагностики зводиться до встановлення істинного стану підприємства з погляду появи загроз:

- визначення місця підприємства в системі розвитку;

- ідентифікація кризових тенденцій, зовнішніх і внутрішніх факторів розгортання кризи;

- енерування достовірної інформації про загрози кризових явищ та про наявність реальної можливості підприємства щодо їх подолання.

Функція прогнозування криз спрямована на передбачення їх характеру, глибини, можливих термінів їх настання, розробку індикаторів, попередження кризових тенденцій. У результаті реалізації даних функцій служба кризового попередження отримує i аналізує інформацію про загальну тенденцію, стадії циклічної динаміки розвитку підприємства, глибини кризових явищ на підприємстві, прогнозних розрахунків подальшого поширення кризи. Для 
забезпечення своєчасного адекватного реагування на загрозу розгортання кризи, служба кризового попередження здійснює функцію планування антикризових заходів, диференційованих за видами кризи. Сплановані заходи щодо профілактики кризи повинні знайти відображення в стратегічному i оперативному планах підприємства, який є альтернативою основного плану.

Висновки. Повністю виключити можливість виникнення кризових явищ у діяльності підприємства неможливо, так як його діяльність обумовлена розвитком економіки. Але кризовим явищам можна протистояти, і чим раніше відбудеться розпізнавання і діагностування настання кризи, тим менш масштабними будуть збитки підприємства.

Превентивне антикризове управління, розуміс здатність прогнозувати причини і момент настання кризи, а у разі об'єктивної неможливості уникнути входження в кризовий період, вжити необхідних заходів щодо протидії кризовим явищам. Його перевага полягає в наявності більш тривалих, проміжків часу між моментами прийняття, реалізації та появи відповідних рішень у керованій системі.

Наукова новизна отриманих результатів полягає у визначенні комплексу заходів та ключових форм інновацій при превентивному управлінні, враховуючи які можна запобігати кризовим проблемам при їх виникненні.

Перспективами подальших досліджень у цьому напрямку є глибоке вивчення антиципативного антикризисного управління та визначення його переваг в діяльності підприємств.

\section{Література:}

1. Друкер П. Эффективное управление предприятием. М.: Вильямс, 2008. - 224c.

2. Коваленко О. В. Сутність, особливості та деякі проблеми превентивного антикризового управління підприємством/О.В. Коваленко//Вісник Національного технічного університету „Харківський політехнічний інститут”. Збірник наукових праць. Тематичний випуск: Технічний прогрес і ефективність виробництва. - Харків: НТУ „ХПІ”. - 2009. - № 5. - С. 99-106.

3. Кунин В.А. Превентивное управление предпринимательскими рисками промышленных предприятий. СПб.: Изд-во СПбАУЭ, 2009.- 349 с.

4. Распопов В.М. Превентивное антикризисное управление : учебное пособие / В.М. Распопов, В.В. Распопов. - М.: Магистр: ИНФРА-М, 2012. - 432 с.

5. Распопов В.М. Управление изменениями: учебное пособие / В.М. Распопов. - М.: Магистр: ИНФРА-М, 2013. -336 с.

6. Руденский Р.А. Антисипативное управление сложными экономическими системами: модели, методы, инструменты: монография / Р.А. Руденский; Донецкий национальный ун-т, НИИ проблем экономической динамики. - Донецк: Юго-Восток, 2009. - 257 с.

7. Шершньова 3.С. Антикризове управління підприємством : Навч. посіб. / [3.С. Шершньова, В.М. Багацький, Н.Д. Гетманцева]; За заг. ред. 3.Є. Шершньової. - К.: KHEУ, 2007. $-680 \mathrm{c}$. 